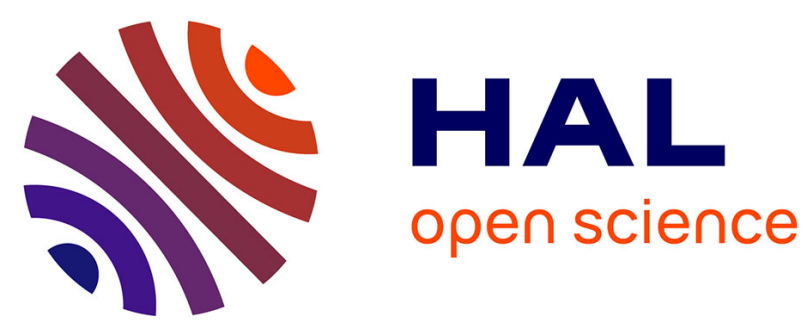

\title{
New synthesis route for glasses and glass-ceramics in the Ga2S3-Na2S binary system
}

\author{
K. Denoue, David Le Coq, C. Calers, A. Gautier, Louisiane Verger, Laurent
} Calvez

\section{- To cite this version:}

K. Denoue, David Le Coq, C. Calers, A. Gautier, Louisiane Verger, et al.. New synthesis route for glasses and glass-ceramics in the Ga2S3-Na2S binary system. Materials Research Bulletin, 2021, 142, pp.111423. 10.1016/j.materresbull.2021.111423 . hal-03284243

\section{HAL Id: hal-03284243 \\ https://hal.science/hal-03284243}

Submitted on 10 Sep 2021

HAL is a multi-disciplinary open access archive for the deposit and dissemination of scientific research documents, whether they are published or not. The documents may come from teaching and research institutions in France or abroad, or from public or private research centers.
L'archive ouverte pluridisciplinaire HAL, est destinée au dépôt et à la diffusion de documents scientifiques de niveau recherche, publiés ou non, émanant des établissements d'enseignement et de recherche français ou étrangers, des laboratoires publics ou privés. 


\title{
New synthesis route for glasses and glass- ceramics in the $\mathrm{Ga}_{2} \mathrm{~S}_{3}-\mathrm{Na}_{2} \mathrm{~S}$ binary system
}

\author{
Killian DENOUE ${ }^{1}$, David LE COQ ${ }^{1, *}$, Christophe CALERS ${ }^{1}$, Antoine GAUTIER ${ }^{1}$, Louisiane VERGER ${ }^{1}$, \\ Laurent CALVEZ ${ }^{1}$ \\ ${ }^{1}$ Univ Rennes, CNRS, ISCR (Institut des Sciences Chimiques de Rennes) - UMR 6226, F-35000 Rennes, France \\ *david.lecoq@univ-rennes1.fr
}

\begin{abstract}
Compositions belonging to the binary system $(100-x)\left[\mathrm{Ga}_{2} \mathrm{~S}_{3}\right]-x\left[\mathrm{Na}_{2} \mathrm{~S}\right]$ (with $\left.10 \leq x \leq 90\right)$ were synthesized by mechanical-alloying. By using the ball-milling technique instead of a usual heating process, the vitreous domain is extended from $24 \leq x \leq 41$ to $20 \leq x \leq 80$. For the first time the conductivity of these glasses has been measured by impedance spectroscopy and an ionic conductivity of $1.9 \times 10^{-6}{\mathrm{~S} . \mathrm{cm}^{-1}}^{\mathrm{at}}$ $25^{\circ} \mathrm{C}$ is achieved for $\mathrm{x}=80$. A glass-ceramic processing from the $\mathrm{Na}_{2} \mathrm{~S}$ richest glass composition is implemented in order to stabilize the sample and to eliminate Na dendrite formation that occurs in the glass during DC current experiments. Finally, this paper shows the positive impact of crystallization and reveals that the glass-ceramization is an interesting process in the framework of synthesis of electrolytes for all-solid-state sodium batteries.
\end{abstract}

\section{Introduction}

Lithium-ion batteries dominate the current energy storage market. They are mainly used for mobile and automotive applications. However, the demand for energy storage devices is constantly growing not only in the automotive sector with electric vehicles, but also for domestic stationary power supplies and large wind and solar farms ${ }^{12} 34$. This increasing demand requires new batteries with higher energy and power density and good reliability. Studies have shown that all-solid-state sulfurbased lithium batteries can have more interesting power and energy density than liquid systems $s^{5}$. The advantage of all-solid-state batteries lies in the use of an inorganic solid electrolyte. It is nonflammable, which means that these batteries do not suffer from leakage or volatilization, which increases their safety, unlike those using liquid electrolyte solutions ${ }^{78}$. Nevertheless, resistance at the different interfaces between solid materials usually limits all-solid-state batteries performances. In addition, during cycling, interphases can form at the interfaces and degrade the performance of these batteries ${ }^{9}$.

Despite a major presence of lithium in secondary batteries, it is not an abundant material in the earth's crust and its price has therefore increased significantly due to geopolitical reason ${ }^{210}$. On the opposite, sodium has almost unlimited resources, a low environmental impact, and is economically more advantageous. Thus, all-solid-state sodium batteries could be a judicious alternative for the next generation of low-cost batteries ${ }^{11} 12$, especially for stationary applications.

Different solid electrolytes have already been developed for sodium batteries, such as the oxide $\beta$ alumina $\mathrm{Na}_{2} \mathrm{O}-11 \mathrm{Al}_{2} \mathrm{O}_{3}$ and NASICON-type $\mathrm{Na}_{3+x} \mathrm{Sc}_{x} \mathrm{Zr}_{2-x}\left(\mathrm{SiO}_{4}\right)_{2}\left(\mathrm{PO}_{4}\right)$ with room temperature conductivities of $1.2 \times 10^{-3} \mathrm{~S} / \mathrm{cm}^{13}$ and $4.0 \times 10^{-3} \mathrm{~S} / \mathrm{cm}^{14}$, respectively. Compared to oxide-based electrolytes, solid sulfide electrolytes have mechanical properties that facilitate electrolyte-electrode 
contact by uniaxial pressing at near-ambient temperatures ${ }^{15}{ }^{16}$. Indeed, sulfur electrolytes have a lower Young's modulus than their oxide counterparts and their increased elasticity participates in maintaining solid-solid contact at the interfaces during variations in electrode volume during chargedischarge cycles ${ }^{17}$. In addition, inorganic vitreous materials, and more specifically sulfur-based glasses, have several advantages such as non-flammability, single ion conduction, and an ionic conductivity generally higher than the one of the corresponding crystal ${ }^{18}$.

Numerous studies have therefore been carried out on sulfur compounds, in particular in $\mathrm{Na}_{2} \mathrm{~S}-\mathrm{X}$ binary and $\mathrm{Na}_{2} \mathrm{~S}-\mathrm{X}-\mathrm{Y}$ ternary-systems, with $\mathrm{X}=\mathrm{P}_{2} \mathrm{~S}_{5}{ }^{15}, \mathrm{GeS}_{2}{ }^{19}$, or $\mathrm{SiS}_{2}{ }^{20}$ and $\mathrm{Y}=\mathrm{Ga}_{2} \mathrm{~S}_{3}{ }^{21}, \mathrm{NaCl}^{22}$, or $\mathrm{SnS}_{2}{ }^{23}$. As a result, room temperature conductivities ranging from $10^{-8} \mathrm{~S} / \mathrm{cm}$ up to more than $10^{-4} \mathrm{~S} / \mathrm{cm}$ have been achieved. However, no electrical conducting data are available on the binary $\mathrm{Ga}_{2} \mathrm{~S}_{3}-\mathrm{Na}_{2} \mathrm{~S}$. To the best of our knowledge, the only referenced work published by Palazzi et al. was essentially devoted to the determination of the vitreous domain obtained by melt quenching, ranging from $76\left[\mathrm{Ga}_{2} \mathrm{~S}_{3}\right]-24\left[\mathrm{Na}_{2} \mathrm{~S}\right]$ to $59\left[\mathrm{Ga}_{2} \mathrm{~S}_{3}\right]-41\left[\mathrm{Na}_{2} \mathrm{~S}\right]{ }^{24}$. Sodium content in glasses obtained by melt quenching method is limited by the problem of sodium diffusion in silica. Therefore, our study focuses on the expansion of the vitreous domain in the pseudo binary $\mathrm{Ga}_{2} \mathrm{~S}_{3}-\mathrm{Na}_{2} \mathrm{~S}$ using high-energy mechanical milling. This technique is a simple, rapid, no-waste, and energy-efficient pathway compared to the melt quenching technique. Moreover, the ball-milling technique offers possibilities to synthesize materials without solvent or gas, metastable phases or materials that usually require high temperatures. Indeed, chalcogenide glasses have already been produced using this synthesis method ${ }^{25} 2627$. Then, composition dependence of ionic conductivities of $(100-x)\left[\mathrm{Ga}_{2} \mathrm{~S}_{3}\right]-\mathrm{x}\left[\mathrm{Na}_{2} \mathrm{~S}\right]$ glasses is examined. Next, a glass-ceramic processing is carried out in order to investigate the impact of the crystallization on the electronic properties that prevents the sodium dendrite formation under current. Finally, the presented method allows an electronical stabilization of the samples meaning that this process is promising to produce high sodium content electrolytes for all-solid-state batteries.

\section{Experimental}

\section{Synthesis}

Compositions belonging to the binary $(100-x)\left[\mathrm{Ga}_{2} \mathrm{~S}_{3}\right]-x\left[\mathrm{Na}_{2} \mathrm{~S}\right]$ (with $\mathrm{x}=10,20,30,40,50,60,70,80$ and 90) were synthesized by mechanical milling using a planetary mill (Fritsch, Pulverisette 7). $5 \mathrm{~g}$ of a mixture of $\mathrm{Na}_{2} \mathrm{~S}$ (Alfa Aesar, 95\% purity) and $\mathrm{Ga}_{2} \mathrm{~S}_{3}$ are weighed in stochiometric proportions. $\mathrm{Ga}_{2} \mathrm{~S}_{3}$ was synthesized by mechanical milling following an experimental process given in a previous report ${ }^{28}$. The starting elements are then hand-ground and the mixture is placed in a zirconia bowl (volume of 45 $\mathrm{mL}$ ) with $\mathrm{ZrO}_{2}$ balls (4 $\mathrm{mm}$ diameter), respecting a ball/powder weight ratio equivalent to 20/1. Mechanochemical synthesis was performed at a speed of $600 \mathrm{rpm}$, until total amorphization. The bowls were opened every hour to scrub and hand grind the material in order to obtain a uniform powder. Finally, $10 \mathrm{~mm}$ diameter pellets with a thickness between 1 and $2 \mathrm{~mm}$ were obtained by vacuum pressing under $1.5 \mathrm{~T}$ the previous synthesized powders. The whole process is carried out under a controlled atmosphere of $\mathrm{N}_{2}$. To study the impact of crystallization on conductivity properties, the previously obtained amorphous pellets were placed in a silica tube sealed under vacuum and annealed at $\mathrm{T}_{\mathrm{x}}+10\left(310^{\circ} \mathrm{C}\right)$ for 24 hours.

\section{Characterization techniques}

X-ray diffraction (XRD) measurements were performed at room temperature on samples protected from air by a Kapton (polyimide) window to avoid moisture corrosion of fine submicron particles. They were recorded in the $10-90^{\circ} 2 \theta$ range with a $0.0261^{\circ}$ step size with each data point having an effective

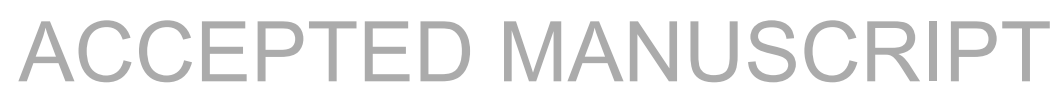


total counting time of $40 \mathrm{~s} / \mathrm{step}$, using a PANalytical X'Pert Pro diffractometer ( $\mathrm{Cu} \mathrm{K}_{\alpha 1}, \mathrm{~K}_{\alpha 2}$ radiations, $\lambda_{\text {K } \alpha 1}=1.54056 \AA, \lambda_{k \alpha 2}=1.54439 \AA, 40 \mathrm{kV}, 40 \mathrm{~mA}$, PIXcel 1D detector). The counting time was multiplied by twelve when it was necessary to reduce the background noise. Data collector and HighScore Plus software were used for recording and analysis of the patterns, respectively.

A differential scanning calorimeter (DSC Q20Thermal Analysis) was used to characterize the thermal properties of the synthesized materials. Measurements were performed from room temperature (RT) up to $550^{\circ} \mathrm{C}$ with a heating rate of $10^{\circ} \mathrm{C} / \mathrm{min}$ under nitrogen atmosphere. Characteristic temperatures including glass transition temperature $\left(T_{g}\right)$ and crystallization onset temperature $\left(T_{x}\right)$ were determined.

Scanning Electron Microscopy (SEM) and Energy Dispersive Spectroscopy (EDS) analysis were collected on JEOL JSM-IT 300 using an acceleration voltage of $15 \mathrm{kV}$ and a magnification $\times 500$ to $\times 3500$ to check the surface, the cross section of pellets and the distribution of elements. To compare the amorphous samples in the pseudo binary system $\mathrm{Ga}_{2} \mathrm{~S}_{3}-\mathrm{Na}_{2} \mathrm{~S}$ with the precursors used, pellets of $\mathrm{Ga}_{2} \mathrm{~S}_{3}$ and $\mathrm{Na}_{2} \mathrm{~S}$ were also vacuum pressed under $1.5 \mathrm{~T}$.

In order to perform electrical measurements, pellets were polished. A thin layer of gold was deposited to ensure good electrical contact with electrodes of the measurement cell. A pressure of approximately $80 \mathrm{kPa}$ was also applied. All measurements were performed with Autolab workstation (PGSTAT302N with FRA32M and ECD module) from $293 \mathrm{~K}$ up to $353 \mathrm{~K}$ with a frequency range from $1 \mathrm{MHz}$ down to 5 $\mathrm{mHz}$ and a signal amplitude of $200 \mathrm{mV}$. A potentiostatic chronoamperometric measurement was used to determine the electronic conductivity. This technique consists of applying a constant potential difference ( $100 \mathrm{mV}$ in our case) to a steel/electrolyte/sodium cell. The resulting current measured once the stabilization is obtained is due to the electron motion.

\section{Results and discussion}

Compositions ranging from (100-x) $\left[\mathrm{Ga}_{2} \mathrm{~S}_{3}\right]-\mathrm{x}\left[\mathrm{Na}_{2} \mathrm{~S}\right]$ with $10 \leq \mathrm{x} \leq 90$ were prepared. The amorphization process has been investigated by $\mathrm{X}$-ray diffraction analyses on fresh powder every $5 \mathrm{~h}$ of milling. As an example, Figure 1-a presents the evolution of amorphization of the $20 \mathrm{Ga}_{2} \mathrm{~S}_{3}-80 \mathrm{Na}_{2} \mathrm{~S}$ composition. $\mathrm{Na}_{2} \mathrm{~S}$ and $\mathrm{Ga}_{2} \mathrm{~S}_{3}$ precursors are detected up to $15 \mathrm{~h}$ of grinding. After $20 \mathrm{~h}$ of milling, their characteristic peaks are not detected anymore, and a supplementary XRD acquisition was then performed with a longer counting time (twelve times more) in order to confirm the absence of any residual peaks. In this case, the compound is therefore considered amorphous. For $(100-x)\left[G_{2} S_{3}\right]-x\left[N_{2} S\right]$ with $20 \leq x \leq 80$, total amorphization has been achieved after $20 \mathrm{~h}$ to $38 \mathrm{~h}$ of milling, showing no dependence with the $\mathrm{Na}_{2} \mathrm{~S}$ amount. However, for compounds with $x=10$ and $x=90$, amorphization by mechanochemistry synthesis was not possible. Indeed, $\mathrm{Ga}_{2} \mathrm{~S}_{3}$ and $\mathrm{Na}_{2} \mathrm{~S}$ are still detected as a majority phase after $15 \mathrm{~h}$ and $25 \mathrm{~h}$ of milling time, respectively. More importantly, no evolution of the residual peaks of $\mathrm{Ga}_{2} \mathrm{~S}_{3}$ and $\mathrm{Na}_{2} \mathrm{~S}$ is observed after an extending milling time up to $20 \mathrm{~h}$ and $30 \mathrm{~h}$, respectively. Consequently, these compounds are considered outside the glassy zone accessible by high-energy milling.

In this study, we found that the glass-forming range of the (100-x) $\left[\mathrm{Ga}_{2} \mathrm{~S}_{3}\right]-\mathrm{x}\left[\mathrm{Na}_{2} \mathrm{~S}\right]$ binary system is 20 $\leq x \leq 80$, meaning that our experimental conditions show a real benefit compared to the work of Palazzi, in which a glassy domain of $24 \leq x \leq 41$ was evidenced ${ }^{24}$. Palazzi used the melt quenching technique in a vitreous carbon nacelle with $\mathrm{GaOOH}$ and $\mathrm{Na}_{2} \mathrm{CO}_{3}$ as starting materials, under a $\mathrm{H}_{2} \mathrm{~S}$ flow $^{24}$. The incorporation of twice as much $\mathrm{Na}^{+}$within the amorphous phase can be explained by the choice of mechanosynthesis: the mechanical energy of the impact of balls against the powder creates a local melting/quenching area in which higher quenching rates occur, possibly higher than $100{ }^{\circ} \mathrm{C} / \mathrm{s}^{29}$. An extended amorphous domain can therefore be potentially reached using mechanical milling. 

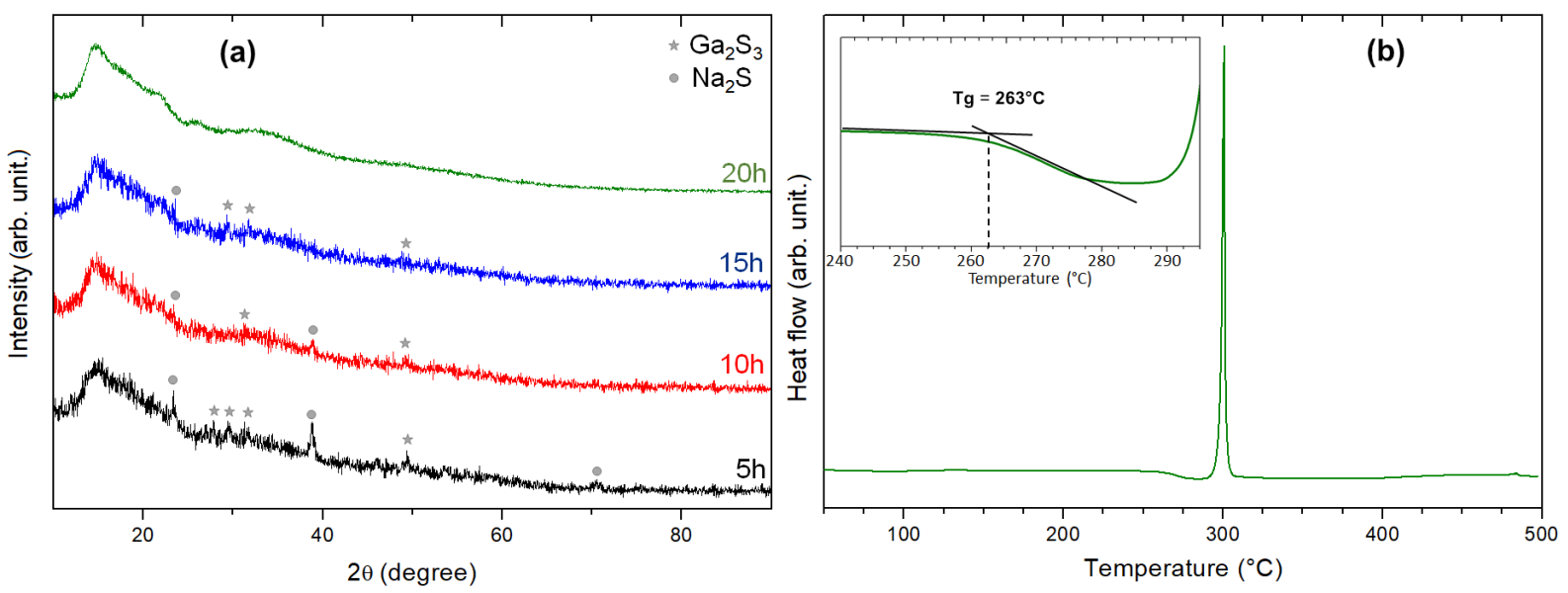

Figure 1: (a) XRD diagrams of $20\left[\mathrm{Ga}_{2} \mathrm{~S}_{3}\right]-80\left[\mathrm{Na}_{2} \mathrm{~S}\right]$ samples prepared by ball milling for different durations. A longer counting was used for the powder after $20 \mathrm{~h}$ of milling in order to improve the statistic. (b) DSC trace of the $20\left[\mathrm{Ga}_{2} \mathrm{~S}_{3}\right]-80\left[\mathrm{Na}_{2} \mathrm{~S}\right]$ sample after $20 \mathrm{~h}$ of milling.

Characteristic temperatures including glass transition temperature $\left(T_{\mathrm{g}}\right)$ and crystallization temperature $\left(T_{x}\right)$ of the synthesized compounds are summarized in Table 1. A typical DSC trace, corresponding to the $20\left[\mathrm{Ga}_{2} \mathrm{~S}_{3}\right]-80\left[\mathrm{Na}_{2} \mathrm{~S}\right]$ samples after $20 \mathrm{~h}$ of milling, is also shown in Figure 1-b. $\mathrm{T}_{\mathrm{g}}$ generally goes up with an increase of the amount of $\mathrm{Ga}_{2} \mathrm{~S}_{3}$. However, $\mathrm{T}_{\mathrm{g}}$ abruptly drops for the $80\left[\mathrm{Ga}_{2} \mathrm{~S}_{3}\right]-2 \mathrm{O}\left[\mathrm{Na}_{2} \mathrm{~S}\right]$. This trend is not surprising. Previous work on $\mathrm{GeS}_{2}-\mathrm{Ga}_{2} \mathrm{~S}_{3}-\mathrm{NaX}$ systems (with $\mathrm{X}=\mathrm{Cl}$ or I) ${ }^{30}$ has shown that $\mathrm{T}_{\mathrm{g}}$ decreases with increasing $\mathrm{Na}$ amount in the composition. This phenomenon extends to other alkaline, as shown on cesium ${ }^{31} 32$ and lithium ${ }^{33}$. The addition of alkaline creates the progressive rupture of the Ga-S bonds leading to a decrease in the connectivity of the glass network. Moreover, it is also mentioned in table 1 that the $60\left[\mathrm{Ga}_{2} \mathrm{~S}_{3}\right]-40\left[\mathrm{Na}_{2} \mathrm{~S}\right]$ compound presents two $\mathrm{T}_{\mathrm{g}}$ that can be due to a phase separation within the glassy matrix. Indeed, the lower $T_{g}$ and $T_{x}$ are close to those of $50\left[G_{2} S_{3}\right]-$ $50\left[\mathrm{Na}_{2} \mathrm{~S}\right]$. No clear trend can be deduced concerning the evolution of $T_{x}$, which can be correlated to the different milling durations that greatly affect this temperature.

Table 1: Characteristics of amorphous compounds belonging to the pseudo binary $\mathrm{Ga}_{2} \mathrm{~S}_{3}-\mathrm{Na}_{2} \mathrm{~S}$ system: onset glass transition temperature $T_{g}$, onset crystallization temperature $T_{x}$, and activation energy $E_{a}$.

\begin{tabular}{|c|c|c|c|c|}
\hline Compound & $\mathrm{T}_{\mathrm{g}}^{\circ}(\mathrm{C})\left( \pm 5^{\circ} \mathrm{C}\right)$ & \multicolumn{2}{|c|}{$\mathrm{T}_{\mathrm{x}}\left({ }^{\circ} \mathrm{C}\right)\left( \pm 5^{\circ} \mathrm{C}\right)$} & $E_{a}(e V)$ \\
\hline $20\left[\mathrm{Ga}_{2} \mathrm{~S}_{3}\right]-80\left[\mathrm{Na}_{2} \mathrm{~S}\right]$ & 263 & \multicolumn{2}{|c|}{298} & $0.574(18)^{*}$ \\
\hline $30\left[\mathrm{Ga}_{2} \mathrm{~S}_{3}\right]-70\left[\mathrm{Na}_{2} \mathrm{~S}\right]$ & 290 & 340 & 419 & $0.592(15)$ \\
\hline $40\left[\mathrm{Ga}_{2} \mathrm{~S}_{3}\right]-60\left[\mathrm{Na}_{2} \mathrm{~S}\right]$ & 285 & \multicolumn{2}{|c|}{324} & $0.551(16)$ \\
\hline $50\left[\mathrm{Ga}_{2} \mathrm{~S}_{3}\right]-50\left[\mathrm{Na}_{2} \mathrm{~S}\right]$ & 304 & \multicolumn{2}{|c|}{405} & $0.540(13)$ \\
\hline $60\left[\mathrm{Ga}_{2} \mathrm{~S}_{3}\right]-40\left[\mathrm{Na}_{2} \mathrm{~S}\right]$ & 300 & \multicolumn{2}{|c|}{394} & $0.524(13)$ \\
\hline $70\left[\mathrm{Ga}_{2} \mathrm{~S}_{3}\right]-30\left[\mathrm{Na}_{2} \mathrm{~S}\right]$ & 449 & & & $0.576(12)$ \\
\hline $80\left[\mathrm{Ga}_{2} \mathrm{~S}_{3}\right]-20\left[\mathrm{Na}_{2} \mathrm{~S}\right]$ & 328 & 437 & $>550$ & $0.604(19)$ \\
\hline
\end{tabular}

*calculation carried out up to $1000 / \mathrm{T}=3.003$.

The amorphous powders were pressed under vacuum $\left(10^{-2} \mathrm{~Pa}\right)$ in a $10 \mathrm{~mm}$ die at room temperature. The obtained pellets were studied by impedance spectroscopy. Insets in Figure 2 show the Nyquist diagrams of compounds $70\left[\mathrm{Ga}_{2} \mathrm{~S}_{3}\right]-30\left[\mathrm{Na}_{2} \mathrm{~S}\right], 50\left[\mathrm{Ga}_{2} \mathrm{~S}_{3}\right]-50\left[\mathrm{Na}_{2} \mathrm{~S}\right]$, and $20\left[\mathrm{Ga}_{2} \mathrm{~S}_{3}\right]-80\left[\mathrm{Na}_{2} \mathrm{~S}\right]$. Two parts differ from this diagram: (i) in the high and medium frequency regions, the semicircle represents the impedance of the sample; and (ii) in the low frequency region, the polarization tail, is typical of a polarization at the electrode. The latter results from the accumulation of charge carriers $\left(\mathrm{Na}^{+}\right)$at pellet- 
electrode interface and is characteristic of ion conductors. It probably means that the conductivity can be assumed to be mainly ionic. From these diagrams collected at different temperatures, a sample resistance $R(\mathrm{Ohm})$, corresponding to the diameter of the semi-circle, is extracted and equation (1) allows to determine the conductivity $\sigma\left(\mathrm{S} . \mathrm{cm}^{-1}\right)$ :

$$
\sigma=e /(R \times S)
$$

With e and S corresponding to the thickness $(\mathrm{cm})$ and the area $\left(\mathrm{cm}^{2}\right)$ of the pellet, respectively.

Figure 2 shows that ionic conductivity increases with the $\mathrm{Na}_{2} \mathrm{~S}$ content measured at $25^{\circ} \mathrm{C}$, following a nonlinear monotonous trend. As expected, the $20\left[\mathrm{Ga}_{2} \mathrm{~S}_{3}\right]-80\left[\mathrm{Na}_{2} \mathrm{~S}\right]$ glass composition, corresponding to the highest $\mathrm{Na}$ content, reaches the highest conductivity $\sigma=1.9 \times 10^{-6} \mathrm{~S} . \mathrm{cm}^{-1}$ at $25^{\circ} \mathrm{C}$, while the lowest $\mathrm{Na}$ content sample $80\left[\mathrm{Ga}_{2} \mathrm{~S}_{3}\right]-20\left[\mathrm{Na}_{2} \mathrm{~S}\right]$ possesses a conductivity of $\sigma=1.6 \times 10^{-10} \mathrm{~S} . \mathrm{cm}^{-1}$. Comparison with the pseudo-binary system $\mathrm{GeS}_{2} / \mathrm{Na}_{2} \mathrm{~S}$ shows that the conductivities at room temperature of $20\left[\mathrm{Ga}_{2} \mathrm{~S}_{3}\right]-80\left[\mathrm{Na}_{2} \mathrm{~S}\right]$ and $50\left[\mathrm{GeS}_{2}\right]-50\left[\mathrm{Na}_{2} \mathrm{~S}\right]\left(\sigma=1 \times 10^{-6}{\left.\mathrm{~S} . \mathrm{cm}^{-1}\right)}^{-1}\right.$ are roughly the same ${ }^{19}$. Figure 3 shows the evolution of the ionic conductivity of each sample as a function of the reverse temperature. As in figure 2, the ionic conductivity increases with the $\mathrm{Na}_{2} \mathrm{~S}$ content, whatever the temperature. For all compounds the conductivity is thermally activated and follows an Arrhenius law:

$$
\sigma=\frac{\sigma_{0}}{T} \times \exp \left(-\frac{E_{a}}{k_{b} T}\right)
$$

With $\sigma_{0}$ the pre-exponential factor $\left(\mathrm{S} . \mathrm{cm}^{-1} \cdot \mathrm{K}\right), T$ the temperature (K), $E_{a}$ the activation energy $(\mathrm{eV})$, and $k_{b}$ the Boltzmann constant.

Nevertheless, two points at $70^{\circ} \mathrm{C}$ and $80^{\circ} \mathrm{C}$ for the $20\left[\mathrm{Ga}_{2} \mathrm{~S}_{3}\right]-80\left[\mathrm{Na}_{2} \mathrm{~S}\right]$ sample do not obey the Arrhenius law (open squares in figure 3 ). This behavior let suppose that an instability of this composition with temperature occurs, which could be characterized by a structural network modification. Indeed, the highest conductivity of all investigated samples, $\sigma=1.6 \times 10^{-4} \mathrm{~S}_{\mathrm{cm}} \mathrm{cm}^{-1}$, is obtained at $80^{\circ} \mathrm{C}$ for this composition. The activation energies, which were calculated from equation 2 , are summarized in Table 1. No influence of the $\mathrm{Na}_{2} \mathrm{~S}$ content is observed and their values are around $0.56 \pm 0.04 \mathrm{eV}$.

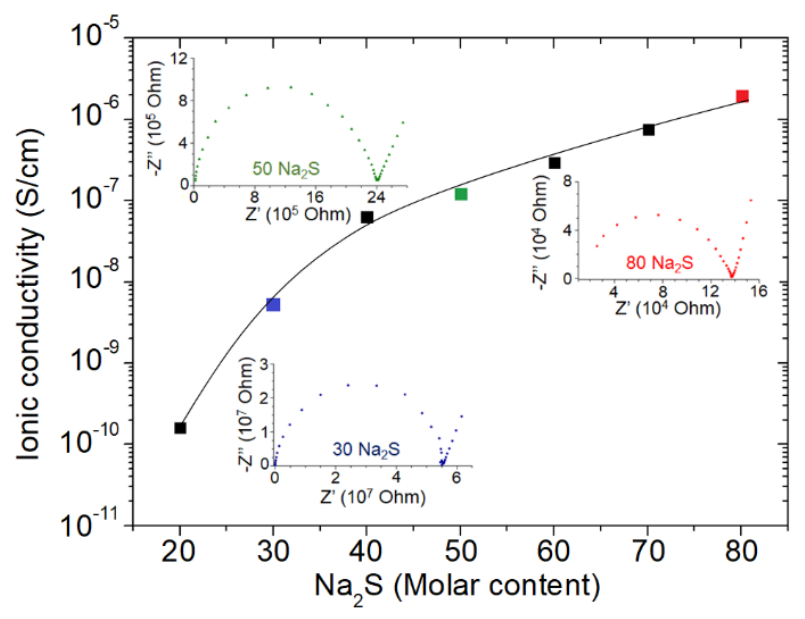

Figure 2: Evolution of the ionic conductivity as a function of the molar percentage of $\mathrm{Na}_{2} \mathrm{~S}$ for the vacuum pressed pellets, at room temperature. The solid line is a guide for the eye. Insets highlight the Nyquist's diagrams for amorphous samples (100-x) $\left[\mathrm{Ga}_{2} \mathrm{~S}_{3}\right]-\mathrm{x}\left[\mathrm{Na}_{2} \mathrm{~S}\right]$, with $\mathrm{x}=30,50$, and 80 at $25^{\circ} \mathrm{C}$. 


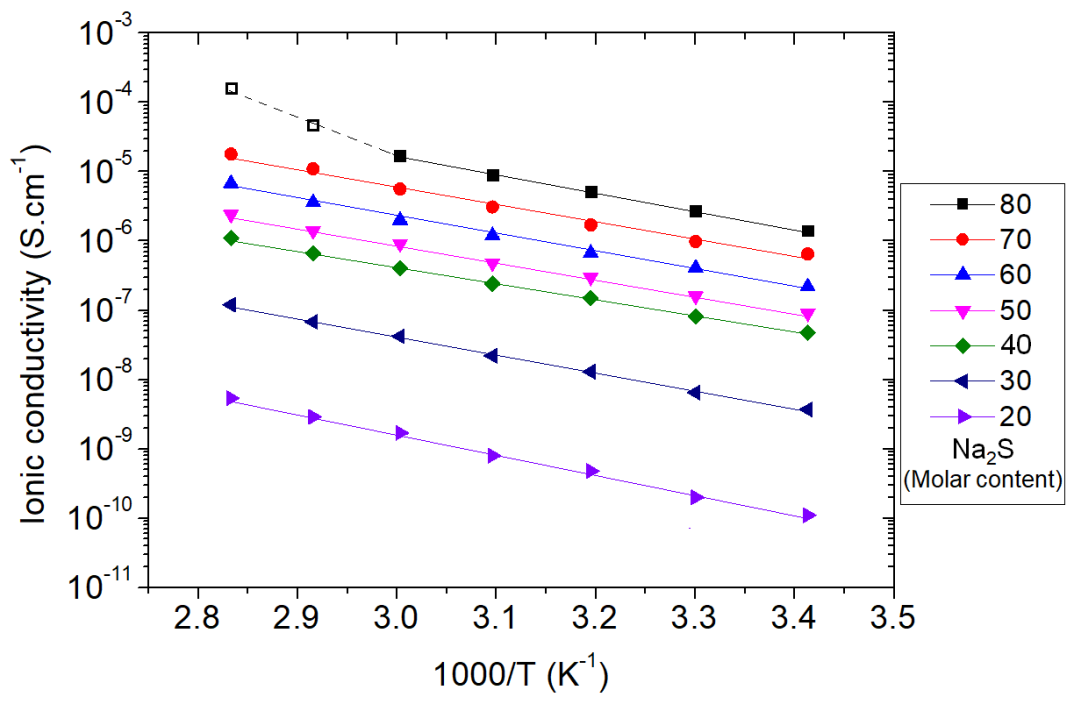

Figure 3: Evolution of the ionic conductivity of vacuum pressed pellets as a function of the reverse temperature. The two open black squares correspond to data for $20\left[\mathrm{Ga}_{2} \mathrm{~S}_{3}\right]-80\left[\mathrm{Na}_{2} \mathrm{~S}\right]$ that do not obey the Arrhenius law.

SEM images were taken from pellets with the following composition: $20\left[\mathrm{Ga}_{2} \mathrm{~S}_{3}\right]-80\left[\mathrm{Na}_{2} \mathrm{~S}\right], 50\left[\mathrm{Ga}_{2} \mathrm{~S}_{3}\right]-$ $50\left[\mathrm{Na}_{2} \mathrm{~S}\right], 80\left[\mathrm{Ga}_{2} \mathrm{~S}_{3}\right]-20\left[\mathrm{Na}_{2} \mathrm{~S}\right], \mathrm{Na}_{2} \mathrm{~S}$, and $\mathrm{Ga}_{2} \mathrm{~S}_{3}$ (figure 4). Despite the same polishing procedure for all samples, the pressed pellets exhibit an increase in surface roughness as the $\mathrm{Na}_{2} \mathrm{~S}$ content decreases (figure $4 a, c$, and e). Images of the cross section highlight that the $20\left[\mathrm{Ga}_{2} \mathrm{~S}_{3}\right]-80\left[\mathrm{Na}_{2} \mathrm{~S}\right]$ sample (figure $4 b)$ shows a uniform texture with pores and induced cracks due to mechanical stresses exerted during shaping, while the $50\left[\mathrm{Ga}_{2} \mathrm{~S}_{3}\right]-50\left[\mathrm{Na}_{2} \mathrm{~S}\right.$ ] (figure $4 \mathrm{~d}$ ) and the $80\left[\mathrm{Ga}_{2} \mathrm{~S}_{3}\right]-20\left[\mathrm{Na}_{2} \mathrm{~S}\right]$ (figure $4 \mathrm{f}$ ) samples exhibit aggregates of particles. A comparison between micrographs $4 \mathrm{~d}$ and $4 \mathrm{f}$ and micrographs $4 \mathrm{~g}$ and $4 \mathrm{~h}$, representing the cross section of $\mathrm{Na}_{2} \mathrm{~S}$ and $\mathrm{Ga}_{2} \mathrm{~S}_{3}$, respectively, reveals that the shape of particle aggregates in high $\mathrm{Ga}_{2} \mathrm{~S}_{3}$ content pellets is similar to those of $\mathrm{Ga}_{2} \mathrm{~S}_{3}$. The $20\left[\mathrm{Ga}_{2} \mathrm{~S}_{3}\right]-80\left[\mathrm{Na}_{2} \mathrm{~S}\right]$ compound is also different from pure $\mathrm{Na}_{2} \mathrm{~S}$. The latter has no real porosity, even if very fine stress cracks can be seen in places during uniaxial pressing, but it has a higher roughness than $20\left[\mathrm{Ga}_{2} \mathrm{~S}_{3}\right]-80\left[\mathrm{Na}_{2} \mathrm{~S}\right]$. Statistics were performed using several SEM images to estimate the porosity of each sample after shaping. The results obtained show an average densification of $90 \% \pm 5 \%$. 


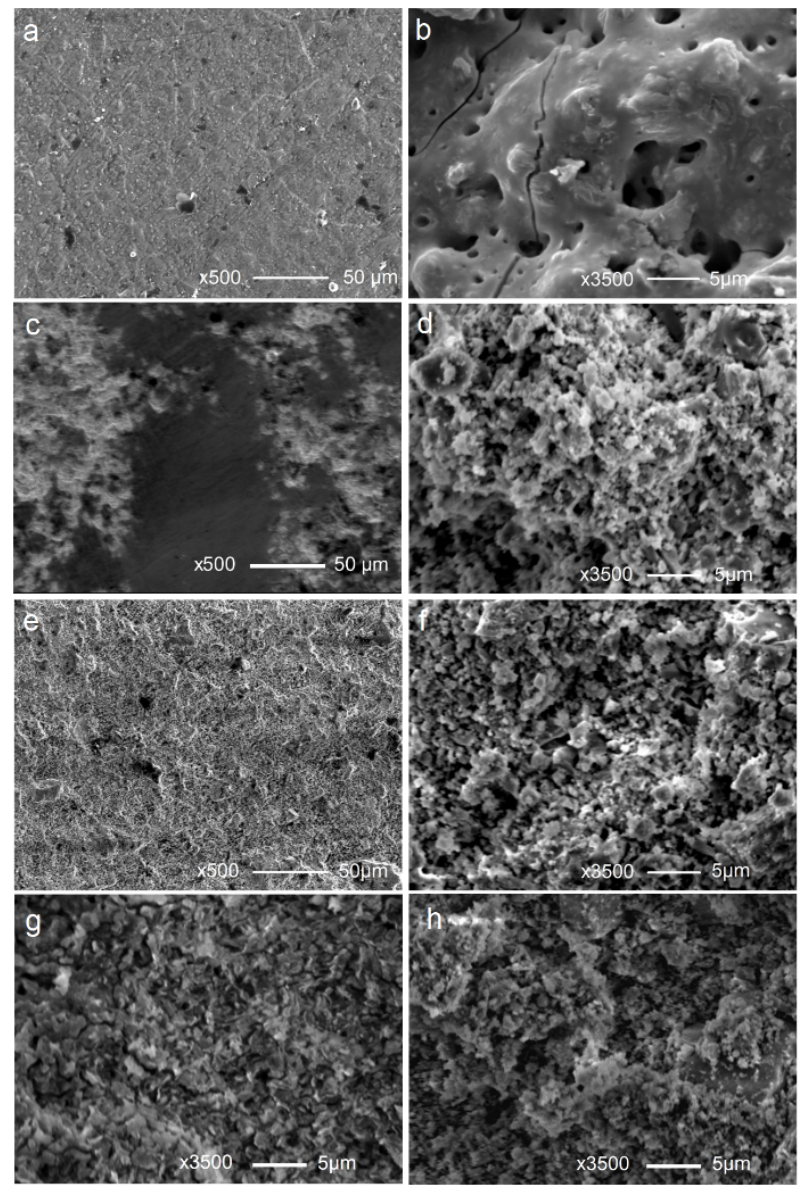

Figure 4: SEM images of the surface (a) and cross section (b) of $20\left[\mathrm{Ga}_{2} \mathrm{~S}_{3}\right]-80\left[\mathrm{Na}_{2} \mathrm{~S}\right]$; the surface (c) and cross section (d) of $50\left[\mathrm{Ga}_{2} \mathrm{~S}_{3}\right]-50\left[\mathrm{Na}_{2} \mathrm{~S}\right]$; the surface (e) and cross section (f) of $80\left[\mathrm{Ga}_{2} \mathrm{~S}_{3}\right]-20\left[\mathrm{Na}_{2} \mathrm{~S}\right]$; the cross sections of $\mathrm{Na}_{2} \mathrm{~S}(\mathrm{~g})$ and $\mathrm{Ga}_{2} \mathrm{~S}_{3}(\mathrm{~h})$.

We focused our investigation on the $20\left[\mathrm{Ga}_{2} \mathrm{~S}_{3}\right]-80\left[\mathrm{Na}_{2} \mathrm{~S}\right]$ compound, which offers the best ionic conductivity. A solid electrolyte must have both a high ionic conductivity and a low electronic conductivity to promote the circulation of electrons outside the circuit and power a device connected to the battery. The electronic conductivity of our compounds has been measured using the potentiostatic chronoamperometric technique. The residual current $l_{\infty}$ is related to the electronic conductivity $\sigma_{\mathrm{e}}$ following equation 3 :

$$
\sigma_{e}=\frac{I_{\infty} \times e}{U \times S}
$$

With $I_{\infty}$ the residual current $(A)$, e the thickness of the sample $(\mathrm{cm}), U$ the voltage $(V)$, and $S$ the surface area of the sample $\left(\mathrm{cm}^{2}\right)$.

Potentiostatic chronoamperometry measurements show that the $20\left[\mathrm{Ga}_{2} \mathrm{~S}_{3}\right]-80\left[\mathrm{Na}_{2} \mathrm{~S}\right]$ compound is not electronically stable: in figure $5 \mathrm{a}$, a continuous increase of the current is observed, instead of a drop followed by a plateau. SEM-EDS mapping operated after measurement shows the formation of Na-rich area on the side of the $20\left[\mathrm{Ga}_{2} \mathrm{~S}_{3}\right]-80\left[\mathrm{Na}_{2} \mathrm{~S}\right]$ pellet in contact with the blocking electrode. This clearly shows the formation of metallic sodium dendrites during measurement, which is likely to happen with this Na-rich composition. 

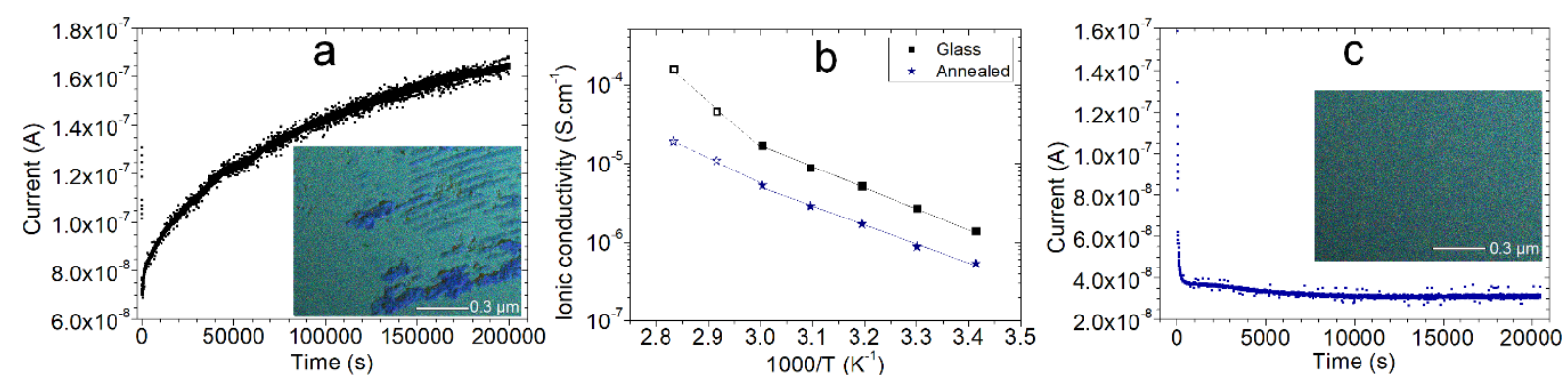

Figure 5: (a) Potentiostatic chronoamperometric measurement of amorphous compound 20[ $\left.\mathrm{Ga}_{2} \mathrm{~S}_{3}\right]-$ $80\left[\mathrm{Na}_{2} \mathrm{~S}\right]$. (b) Comparison of the ionic conductivity between amorphous compound $20\left[\mathrm{Ga}_{2} \mathrm{~S}_{3}\right]-80\left[\mathrm{Na}_{2} \mathrm{~S}\right]$ and annealed $20\left[\mathrm{Ga}_{2} \mathrm{~S}_{3}\right]-80\left[\mathrm{Na}_{2} \mathrm{~S}\right]$ at $310^{\circ} \mathrm{C}$ for $24 \mathrm{~h}$ as a function of the reverse temperature. (c) Potentiostatic chronoamperometric measurement of the annealed $20\left[\mathrm{Ga}_{2} \mathrm{~S}_{3}\right]-80\left[\mathrm{Na}_{2} \mathrm{~S}\right]$ sample at $310^{\circ} \mathrm{C}$ for $24 \mathrm{~h}$. The insets are EDS mappings of a fragment of the respective pellets after measurement, with $\mathrm{Ga}$ in red, $\mathrm{S}$ in green, and $\mathrm{Na}$ in blue.

Consequently, even if the ionic conductivity of this sample is promising, the growth of metallic sodium dendrites during potentiostatic chronoamperometry experiments requires a new or adapted strategy. Literature reveals the existence of superconducting phases by crystallizing amorphous compounds, such as $\mathrm{Na}_{3} \mathrm{PS}_{4}{ }^{15}$. Crystallization experiments were therefore carried out using the amorphous $20\left[\mathrm{Ga}_{2} \mathrm{~S}_{3}\right]-80\left[\mathrm{Na}_{2} \mathrm{~S}\right]$ sample. Pellets of amorphous $20\left[\mathrm{Ga}_{2} \mathrm{~S}_{3}\right]-80\left[\mathrm{Na}_{2} \mathrm{~S}\right]$ were placed in a vacuum-sealed tube and put in an annealing furnace at $\mathrm{T}_{x}+10\left(310^{\circ} \mathrm{C}\right)$ for 24 hours. These annealing parameters were fixed after many experimental attempts from which the aim was the obtention of a thin and homogeneous crystalline powder. The diffractogram obtained (figure 6), reveals the presence of two polymorphs of $\mathrm{GaNa}_{3} \mathrm{~S}_{3}$ : I-GaNa $\mathrm{S}_{3}$ (JCPDS no. 01-084-2770) and II-GaNa $\mathrm{S}_{3}$ (JCPDS no. 01-084-2771). Two peaks between 16 and $17^{\circ}$ are not indexed by these phases. $\mathrm{GaNa}_{3} \mathrm{~S}_{3}$ corresponds to a starting stoichiometry of $25\left[\mathrm{Ga}_{2} \mathrm{~S}_{3}\right]-75\left[\mathrm{Na}_{2} \mathrm{~S}\right]$. Thus, there is an excess of $\mathrm{Na}_{2} \mathrm{~S}$ that might react with the silica tube and form NaSi (JCPDS no. 00-019-1231) and S (JCPDS no. 01-078-0793). Nevertheless, EDS analyses do not reveal the presence of $\mathrm{Si}$ in the material and consequently the peaks not indexed by $\mathrm{GaNa}_{3} \mathrm{~S}_{3}$ are attributed to sulfur. It can also be underlined that the synthesis of I- and II- $\mathrm{GaNa}_{3} \mathrm{~S}_{3}$ has already been reported in the literature by heating stoichiometric amounts of $\mathrm{Ga}, \mathrm{Na}$, and $\mathrm{S}$ in a graphitized quartz glass tube sealed under vacuum at about 650 and $800^{\circ} \mathrm{C}$, respectively ${ }^{34}$. We prove here that $\mathrm{GaNa}_{3} \mathrm{~S}_{3}$ can be synthesized at lower temperature $\left(310^{\circ} \mathrm{C}\right)$ by crystallization of an amorphous precursor. Supplementary investigations are in progress on the $25\left[\mathrm{Ga}_{2} \mathrm{~S}_{3}\right]-75\left[\mathrm{Na}_{2} \mathrm{~S}\right]$ composition to more specifically evaluate the impact of milling on the polymorph obtained. 


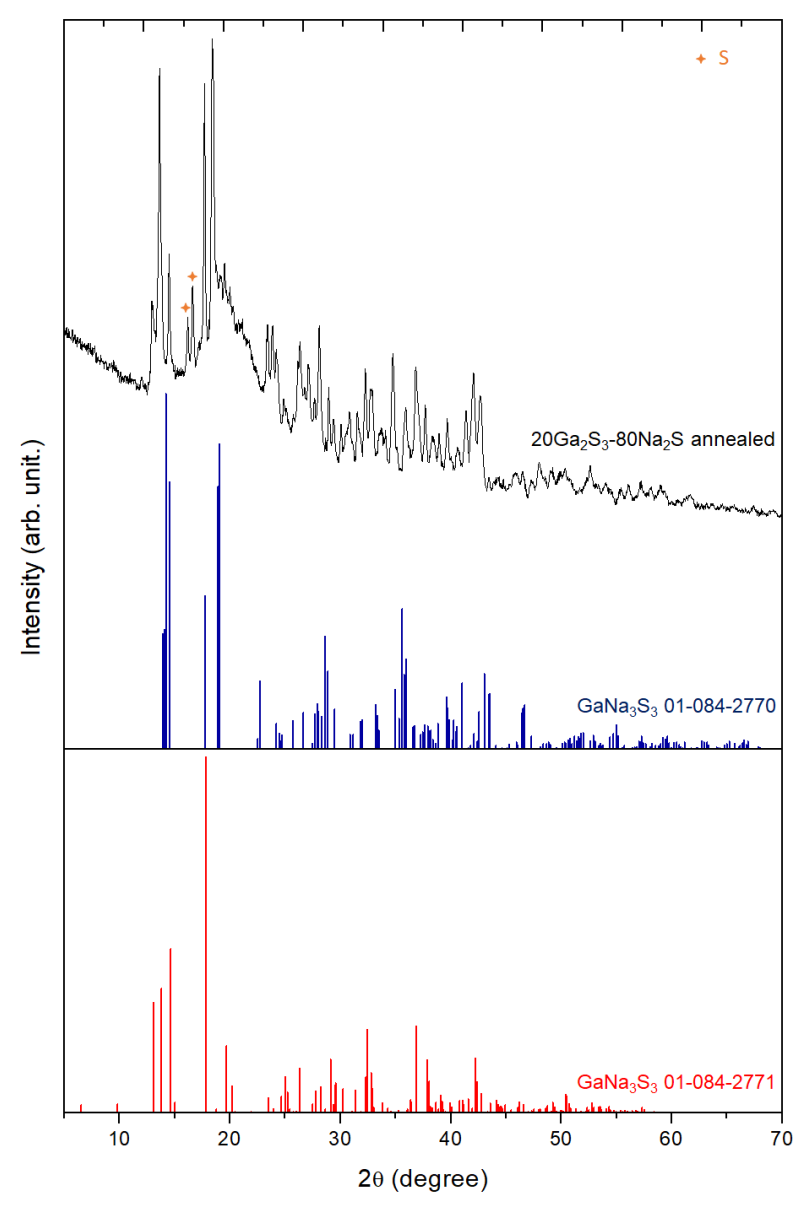

Figure 6: XRD diagram of $20\left[\mathrm{Ga}_{2} \mathrm{~S}_{3}\right]-80\left[\mathrm{Na}_{2} \mathrm{~S}\right]$ samples annealed at $310^{\circ} \mathrm{C}$ for $24 \mathrm{~h}$. The two lowermost diagrams represent the peaks position of the two monoclinic $\mathrm{GaNa}_{3} \mathrm{~S}_{3}$ polymorphs (JCPDS no. 01-0842770 and JCPDS no. 01-084-2771).

Complex impedance and potentiostatic chronoamperometric measurements were performed in order to evaluate the ionic and electronic contribution in the conductivity of the glass-ceramic compound (figures $5 \mathrm{~b}$ and $5 \mathrm{c}$ ). First, the ionic conductivity at $25^{\circ} \mathrm{C}$ of the glass-ceramic compound appears to be slightly lower than for the amorphous sample $\left(\sigma_{\text {glass-ceramic }}=7.1 \times 10^{-7}{\mathrm{~S} . \mathrm{cm}^{-1}}\right.$ and $\sigma_{\text {glass }}=1.9 \times 10^{-6} \mathrm{~S} . \mathrm{cm}^{-}$ $\left.{ }^{1}\right)$. Compared to other glass compounds of the binary system, the value of $\sigma_{\text {glass-ceramic }}$ is similar to the conductivity of the $30\left[\mathrm{Ga}_{2} \mathrm{~S}_{3}\right]-70\left[\mathrm{Na}_{2} \mathrm{~S}\right]$ glass $\left(\sigma=7.5 \times 10^{-7} \mathrm{~S} . \mathrm{cm}^{-1}\right)$. We also noticed that the deviation to the Arrhenius law observed for the two highest temperatures in the glass sample is deeply reduced in the glass-ceramic. These data clearly support the structural stabilization of the composition by ceramization. Secondly, the potentiostatic chronoamperometric measurement shows that the compound is electronically stable (Figure $5 \mathrm{c}$ ). Indeed, a current drop followed by a plateau is observed, the latter corresponding to the residual current within the material. According to equation (3), an electronic conductivity $\sigma_{e}=5.8 \times 10^{-8} \mathrm{~S} . \mathrm{cm}^{-1}$ is calculated, which is approximately 12 times lower than the ionic conductivity. Moreover, EDS mapping of this compound (figure $5 \mathrm{c}$ ) shows a homogeneous distribution of the elements ( $\mathrm{Ga}, \mathrm{S}$, and $\mathrm{Na}$ ) after measurement and does not show dendrites. These results are consistent with the potentiostatic chronoamperometry measurement and confirm its electronic stability. In summary, the strategy implemented to stabilize compounds of the chosen binary system by a glass-ceramic processing turned out to be promising, with a potential as solid-state electrolyte for sodium batteries. Nevertheless, from a solid electrolyte point of view, since the 
difference between $\sigma_{i}$ and $\sigma_{e}$ is still low, some adjustments in the composition have to be done to increase it. Consequently, future investigations must be devoted to reducing the electronic conductivity. One judicious way could consist in the addition of an electronegative element in the composition, such as chlorine, to prevent the electron motion in the compounds. Thus, a substitution of a part of $\mathrm{Na}_{2} \mathrm{~S}$ by $\mathrm{NaCl}$ have to be considered. Another way could be the addition of a low content of a network former - modifier as for example ( $\mathrm{Si}, \mathrm{Sn}, \mathrm{In}, \mathrm{Ge}, . .$.$) . Moreover, the conductivity is not the$ only key parameter for a good solid electrolyte, and further investigations should be carried out to determine its chemical stability with regard to the electrodes and to determine its electrochemical behavior during cycling tests, especially at the electrolyte-electrode interfaces.

\section{Conclusion}

This work shows that the glass-forming region of the (100-x) $\left[\mathrm{Ga}_{2} \mathrm{~S}_{3}\right]-\mathrm{x}\left[\mathrm{Na}_{2} \mathrm{~S}\right]$ pseudo-binary system can be extended to $20 \leq x \leq 80$ by mechanical-milling synthesis. Conductivities of pressed pellets of amorphous powders were measured for the first time. This study shows that the higher the $\mathrm{Na}_{2} \mathrm{~S}$ content is, the lower the $\mathrm{T}_{\mathrm{g}}$ is and the higher the conductivities are. The best ionic conductivity is obtained for the glass composition $20\left[\mathrm{Ga}_{2} \mathrm{~S}_{3}\right]-\left[80 \mathrm{Na}_{2} \mathrm{~S}\right]$ with $\sigma=1.9 \times 10^{-6} \mathrm{~S} . \mathrm{cm}^{-1}$ at $25^{\circ} \mathrm{C}$ and $\sigma=1.6 \mathrm{x}$ $10^{-4}{\mathrm{~S} . \mathrm{cm}^{-1}}^{-1}$ at $80^{\circ} \mathrm{C}$. Unfortunately, this compound is unstable since the formation of sodium dendrites is observed once it is under current. In order to thwart the dendritic growing, a glass-ceramic processing was operated. Its crystallization mainly reveals the formation of $\mathrm{GaNa}_{3} \mathrm{~S}_{3}$ polymorphs. The conductivity of the glass-ceramic is lightly lower than for the glass counterpart but the crystallized sample has the advantage to be electronically stable. Even if the ratio between $\sigma_{i}$ and $\sigma_{e}$ is still too low to positively consider application as solid electrolyte in all-solid-state sodium batteries, the presented results are very promising from a methodological aspect.

\section{Acknowledgment}

Authors would like to acknowledge the IUF (Institut Universitaire de France). This publication is supported by the European Union through the European Regional Development Fund (ERDF), the Ministry of Higher Education and Research, the French region of Brittany and Rennes Métropole.

\section{References}

(1) Yang, Z.; Zhang, J.; Kintner-Meyer, M. C. W.; Lu, X.; Choi, D.; Lemmon, J. P.; Liu, J. Electrochemical Energy Storage for Green Grid. Chem. Rev. 2011, 111, 5, 3577-3613.

(2) Hwang, J. Y.; Myung, S. T.; Sun, Y. K. Sodium-Ion Batteries: Present and Future. Chem. Soc. Rev. 2017, 46, 3529-3614.

(3) Hueso, K. B.; Armand, M.; Rojo, T. High Temperature Sodium Batteries: Status, Challenges and Future Trends. Energy Environ. Sci. 2013, 6, 734-749.

(4) Pan, H.; Hu, Y. S.; Chen, L. Room-Temperature Stationary Sodium-Ion Batteries for Large-Scale Electric Energy Storage. Energy Environ. Sci. 2013, 6, 2338-2360.

(5) Kamaya, N.; Homma, K.; Yamakawa, Y.; Hirayama, M.; Kanno, R.; Yonemura, M.; Kamiyama, T.; Kato, Y.; Hama, S.; Kawamoto, K.; Mitsui, A. A Lithium Superionic Conductor. Nat. Mater. 2011, 10, 682-686. 
(6) Kato, Y.; Hori, S.; Saito, T.; Suzuki, K.; Hirayama, M.; Mitsui, A.; Yonemura, M.; Iba, H.; Kanno, R. High-Power All-Solid-State Batteries Using Sulfide Superionic Conductors. Nat. Energy 2016, 1,16030 .

(7) Tarascon, J. M.; Armand, M. Issues and Challenges Facing Rechargeable Lithium Batteries. Nature 2001, 414, 359-367.

(8) Armand, M.; Tarascon, J. M. Building Better Batteries. Nature. 2008, 451, 652-657.

(9) Banerjee, A.; Wang, X.; Fang, C.; Wu, E. A.; Meng, Y. S. Interfaces and Interphases in All-SolidState Batteries with Inorganic Solid Electrolytes. Chem. Rev. 2020, 120 (14), 6878-6933.

(10) Kumar, D.; Rajouria, S. K.; Kuhar, S. B.; Kanchan, D. K. Progress and Prospects of Sodium-Sulfur Batteries: A Review. Solid State Ionics 2017, 312, 8-16.

(11) Yabuuchi, N.; Kubota, K.; Dahbi, M.; Komaba, S. Research Development on Sodium-lon Batteries. Chem. Rev. 2014, 114 (23), 11636-11682.

(12) Ellis, B. L.; Nazar, L. F. Sodium and Sodium-Ion Energy Storage Batteries. Current Opinion in Solid State and Materials Science. 2012, 16, 168-177.

(13) Hooper, A. A Study of the Electrical Properties of Single-Crystal and Polycrystalline $\beta$-Alumina Using Complex Plane Analysis. J. Phys. D. Appl. Phys. 1977, 10 (11), 1487-1496.

(14) Ma, Q.; Guin, M.; Naqash, S.; Tsai, C. L.; Tietz, F.; Guillon, O. Scandium-Substituted $\mathrm{Na}_{3} \mathrm{Zr}_{2}(\mathrm{SiO} 4)_{2}\left(\mathrm{PO}_{4}\right)$ Prepared by a Solution-Assisted Solid-State Reaction Method as SodiumIon Conductors. Chem. Mater. 2016, 28 (13), 4821-4828.

(15) Hayashi, A.; Noi, K.; Sakuda, A.; Tatsumisago, M. Superionic Glass-Ceramic Electrolytes for Room-Temperature Rechargeable Sodium Batteries. Nat. Commun. 2012, 3 (1), 1-5.

(16) Fan, B.; Xue, B.; Luo, Z.; Zhang, X.; Ma, H.; Calvez, L. Pressure Dependence of Interfacial Resistance in Pellets Made from $\mathrm{GeS}_{2}-\mathrm{Ga}_{2} \mathrm{~S}_{3}-\mathrm{Li}_{2} \mathrm{~S}$-Lil Glass Powder. J. Am. Ceram. Soc. 2019, $102(3), 1122-1127$.

(17) Sakuda, A.; Hayashi, A.; Tatsumisago, M. Sulfide Solid Electrolyte with Favorable Mechanical Property for All-Solid-State Lithium Battery. Sci. Rep. 2013, 3, 2261.

(18) Viallet, V.; Seznec, V.; Hayashi, A.; Tatsumisago, M.; Pradel, A. Glasses and Glass-Ceramics for Solid-State Battery Applications. Springer Handbooks. 2019; pp 1697-1754. https://doi.org/10.1007/978-3-319-93728-1_50.

(19) Souquet, J. L.; Robinel, E.; Barrau, B.; Ribes, M. Glass Formation and lonic Conduction in the $\mathrm{M}_{2} \mathrm{~S}-\mathrm{GeS}_{2}(\mathrm{M}=\mathrm{Li}, \mathrm{Na}, \mathrm{Ag})$ Systems. Solid State lonics 1981, 3-4, 317-321.

(20) Ribes, M.; Barrau, B.; Souquet, J. L. Sulfide Glasses: Glass Forming Region, Structure and lonic Conduction of Glasses in $\mathrm{Na}_{2} \mathrm{SXS}_{2}(\mathrm{X}=\mathrm{Si} ; \mathrm{Ge}), \mathrm{Na}_{2} \mathrm{~S}-\mathrm{P}_{2} \mathrm{~S}_{5}$ and $\mathrm{Li}_{2} \mathrm{~S}-\mathrm{GeS}_{2}$ Systems. J. Non. Cryst. Solids 1980, 38-39 (Part 1), 271-276.

(21) Yao, W.; Berg, K.; Martin, S. Structure and Properties of Glasses in the $\mathrm{MI}+\mathrm{M}_{2} \mathrm{~S}+\left(0.1 \mathrm{Ga}_{2} \mathrm{~S}_{3}+\right.$ $0.9 \mathrm{GeS}_{2}$ ), M = Li, Na, K and Cs, System. J. Non. Cryst. Solids 2008, 354 (18), 2045-2053.

(22) Chu, I. H.; Kompella, C. S.; Nguyen, H.; Zhu, Z.; Hy, S.; Deng, Z.; Meng, Y. S.; Ong, S. P. RoomTemperature All-Solid-State Rechargeable Sodium-Ion Batteries with a Cl-Doped $\mathrm{Na}_{3} \mathrm{PS}_{4}$ Superionic Conductor. Sci. Rep. 2016, 6, 33733.

(23) Zhang, Z.; Ramos, E.; Lalère, F.; Assoud, A.; Kaup, K.; Hartman, P.; Nazar, L. F. $\mathrm{Na}_{11} \mathrm{Sn}_{2} \mathrm{PS}_{12}$ : A New Solid State Sodium Superionic Conductor. Energy Environ. Sci. 2018, 11 (1), 87-93. 
(24) M. Palazzi. Etude Du Système $\mathrm{Ga}_{2} \mathrm{~S}_{3}-\mathrm{Na}_{2} \mathrm{~S}$. Mise En Évidence d'une Zone Formatrice de Verre. C.R. Acad. Sc. Paris 1984, 299 (9).

(25) Sekine, M.; Suzuki, Y.; Ueno, H.; Onodera, Y.; Usuki, T.; Nasu, T.; Wei, S. Appearance of Fast Ionic Conduction in Agl-Doped Chalcogenide Glass Powders Prepared by Mechanical Milling. J. Non. Cryst. Solids 2007, 353 (18-21), 2069-2073.

(26) Tatsumisago, M.; Hayashi, A. Chalcogenide Glasses as Electrolytes for Batteries. In Chalcogenide Glasses; Elsevier Ltd., 2014, 632-654.

https://doi.org/10.1533/9780857093561.2.632.

(27) Pradel, A.; Ribes, M. Ionic Conductivity of Chalcogenide Glasses. In Chalcogenide Glasses; Elsevier Ltd., 2013; 169-208. https://doi.org/10.1533/9780857093561.1.169.

(28) Dénoue, K.; Cheviré, F.; Calers, C.; Verger, L.; Le Coq, D.; Calvez, L. Mechanochemical Synthesis and Structural Characterization of Gallium Sulfide $\mathrm{Ga}_{2} \mathrm{~S}_{3}$. J. Solid State Chem. 2020, 292, 121743.

(29) Xue, B.; Calvez, L.; Allix, M.; Delaizir, G.; Zhang, X.-H. Amorphization by Mechanical Milling for Making IR Transparent Glass-Ceramics. J. Am. Ceram. Soc. 2016, 99 (5), 1573-1578.

(30) Bréhault, A.; Cozic, S.; Boidin, R.; Calvez, L.; Bychkov, E.; Masselin, P.; Zhang, X.; Le Coq, D. Influence of $\mathrm{NaX}(\mathrm{X}=\mathrm{I}$ or $\mathrm{Cl})$ Additions on $\mathrm{GeS}_{2}-\mathrm{Ga}_{2} \mathrm{~S}_{3}$ based Glasses. J. Solid State Chem. 2014, $220,238-244$.

(31) Masselin, P.; Le Coq, D.; Calvez, L.; Petracovschi, E.; Lépine, E.; Bychkov, E.; Zhang, X. CsCl Effect on the Optical Properties of the $80 \mathrm{GeS}_{2}-20 \mathrm{Ga}_{2} \mathrm{~S}_{3}$ Base Glass. Appl. Phys. A Mater. Sci. Process. 2012, 106 (3), 697-702.

(32) Lin, C.; Qu, G.; Li, Z.; Dai, S.; Ma, H.; Xu, T.; Nie, Q.; Zhang, X. Correlation Between Crystallization Behavior and Network Structure in $\mathrm{GeS}_{2}-\mathrm{Ga}_{2} \mathrm{~S}_{3}-\mathrm{Csl}$ Chalcogenide Glasses. J. Am. Ceram. Soc. 2013, 96 (6), 1779-1782.

(33) Cozic, S.; Bréhault, A.; Le Coq, D.; Usuki, T. GeS $2-\mathrm{Ga}_{2} \mathrm{~S}_{3}-\mathrm{LiCl}$ Glass System: Electrical Conductivity and Structural Considerations. Int. J. Appl. Glas. Sci. 2016, 7 (4), 513-523.

(34) B. Eisenmann and A. Hofmann. Crystal Structure of Hexasodium Di-/i-Thiobis( Dithiogallate) I, $\mathrm{Na}_{6} \mathrm{Ga}_{2} \mathrm{~S}_{6}$. Zeitschrift für Krist. 1991, 197, 143-144.

(35) Eisenmann, B.; Hofmann, A. Crystal Structure of Hexasodium Di- $\mu$-Thio-Bis(Dithiogallate) - II, $\mathrm{Na}_{6} \mathrm{Ga}_{2} \mathrm{~S}_{6}$. Zeitschrift fur Krist. - New Cryst. Struct. 1991, 197, 147-148. 